\title{
Screening for pancreatic cancer: what can cyst fluid analysis tell us?
}

\author{
Walter G. Park
}

Address: Division of Gastroenterology \& Hepatology, Department of Medicine, Stanford University School of Medicine, 300 Pasteur Drive, H0262, MC: 5244, Stanford, CA, 94305, USA

Email:wgpark@stanford.edu

FI000 Medicine Reports 20II, 3:3 (doi:10.34I0/M3-3)

This is an open-access article distributed under the terms of the Creative Commons Attribution-Non Commercial License (http://creativecommons.org/licenses/by-nc/3.0/legalcode), which permits unrestricted use, distribution, and reproduction in any medium, provided the original work is properly cited. You may not use this work for commercial purposes.

The electronic version of this article is the complete one and can be found at: http://fl000.com/reports/m/3/3

\begin{abstract}
Pancreatic cysts are increasingly recognized as a dilemma in clinical practice because of their uncertain risk of malignancy. Because diagnosis by cytology is insensitive, current guidelines suggest using radiographic and clinical criteria to determine the appropriateness of surgery or surveillance, although this is far from perfect. Several cyst fluid biomarkers have been reported to aid diagnosis, and to date, carcinoembryonic antigen is the most accurate in detecting potentially cancerous mucinous cysts, but not in detecting malignant cysts. Recent studies have highlighted novel cyst fluid biomarkers based on DNA analysis, protein expression profiling, and secreted proteins that, if validated, may improve diagnosis and management.
\end{abstract}

Any physician who has had to tell a patient that they have pancreatic cancer will appreciate the importance of proper screening of cysts. Pancreatic cancer, although fairly rare, is almost invariably fatal once symptomatic. Pancreatic cysts by contrast are relatively common and, if small, are generally benign, whereas the surgery to remove them (pancreatic resection) is major and can lead to complications and occasionally death. Surgery carries a much higher risk of mortality in older patients (particularly those with multiple comorbidities), and if the premalignant cancer is not actually malignant, often observation is better than surgery. Therein lies the dilemma for the clinician and the need for accurate tools to differentiate between benign, potentially cancerous, and cancerous cysts, which are so far lacking.

In contrast to earlier estimates, it turns out that the majority of pancreatic cystic lesions are not pseudocysts (organized collections of fluid around the pancreas) but neoplastic cystic lesions [1]. There are three major types of cyst: serous cystadenoma (SCA), mucinous cystic neoplasm $(\mathrm{MCN})$, and intraductal papillary mucinous neoplasm (IPMN). Pseudocysts and SCA lesions are nonmucinous and lack malignant potential. MCN and IPMN lesions are mucinous cysts with recognized potential to become pancreatic cancer. Once a cyst is identified, the clinician must determine whether it is a mucinous cyst and, if so, whether it is malignant.

Because there is no accepted safe and reliable technique to acquire pancreatic tissue without surgery, consensus guidelines were created to identify patients at risk who require surgery [2]. They recommend surgical resection for suspected IPMN lesions with main duct involvement and MCN lesions in surgically fit patients. IPMN lesions with branch duct involvement can be observed if (a) the cyst size is less than $3 \mathrm{~cm}$, (b) there is absence of an intracystic mural nodule, (c) the patient is asymptomatic, (d) the main pancreatic duct is less than $6 \mathrm{~mm}$ wide, and (e) cyst fluid cytology is negative for cancer. Based on available data, the guidelines employ imaging and clinical characteristics to discriminate between the types of cystic lesions. While subsequent validation studies generally support these recommendations, there are instances where the guidelines are suboptimal [3-7]. For example, in one tertiary medical center, preoperative diagnosis in one-third of their surgical cases was incorrect [8]. Imaging has limited diagnostic accuracy ( $40 \%$ ) because the different types of cysts have substantially overlapping radiographic features [9]. The 
sensitivity of cyst fluid cytology is also low (32-50\%) because the fluid is relatively acellular $[10,11]$. Given this state of affairs, cyst fluid biomarker discovery is appealing because it is easy to obtain with endoscopic ultrasound. Also, cyst fluid has the advantage in that it appears to be relatively isolated from serum so, theoretically at least, it contains only secreted biological material from the epithelial cyst lining. To date, several tests using cyst fluid to diagnose premalignant cysts are in use. These include cytology, tumor markers (i.e., carcinoembryonic antigen [CEA], carbohydrate antigen [CA] 19-9, and CA 72-4), biochemical markers (i.e., amylase), cyst fluid viscosity, and various stains (i.e., the periodic acid-Schiff staining method and mucin) $[12,13]$. Among these options, the tumor marker CEA has the highest diagnostic accuracy of $79 \%$ (sensitivity $73 \%$, specificity $84 \%$ ) for discriminating premalignant mucinous cysts from nonmucinous cysts [10]. CEA, however, cannot differentiate a benign premalignant cyst from a malignant cyst. This matters in the clinic because current evidence suggests the natural history of progression to malignancy is slow [14]. Because of this and the associated morbidity of pancreatic resection, surgery is not recommended for all premalignant cysts, and this is particularly true in the elderly.

Understandably, therefore, there has been much interest in several recent studies on novel cyst fluid-based biomarkers (DNA or novel proteins; see Table 1). The largest study [11] was a multicenter prospective study that evaluated the usefulness of DNA analysis in cyst fluid, obtained using endoscopic ultrasound. The quality and quantity of DNA, the presence of a K-ras mutation, and the mean allelic loss amplitude (a relative measure of the proportion of DNA in a cell with hemizygous loss) could accurately differentiate benign nonmucinous from potentially cancerous mucinous cysts among 113 patients with a histological diagnosis. The presence of K-ras mutations alone had a sensitivity of $45 \%$ and specificity of $96 \%$. Adding this to CEA increased the sensitivity for mucinous cysts from $64 \%$ to $82 \%$ without compromising specificity. While the presence of a K-ras mutation did not differentiate benign mucinous cysts from malignant cysts, other aspects of DNA analysis appeared to independently predict malignant cysts. A retrospective study found that the concordance rate between cyst fluid CEA and DNA in predicting mucinous cysts among 83 patients was poor [15], although in the 19 patients with histological data, CEA was more accurate. If CEA and DNA analysis were combined, however, the diagnostic accuracy was perfect for this small sample.

Besides DNA-based markers, differential secretion of proteins into the cyst fluid can also identify mucinous cysts. One group evaluated whether differences in expression levels of 54 proteins associated with pancreatic cancer might exist between nonmucinous and mucinous cysts [16]. Cyst fluid with histological correlation was obtained from 15 patients with SCA, 12 patients with noninvasive $\mathrm{MCN}$, and 32 patients with noninvasive IPMN. Comparing SCA and IPMN cystic lesions, 34 proteins were differentially expressed, whereas comparing SCA and MCN cystic lesions, 13 proteins were differentially expressed. Based on this, the investigators constructed a classification system capable of differentiating SCA and IPMN cystic lesions with 92\% accuracy.

Another study evaluated the presence of mucin 1 (MUC1), MUC5AC, MUC16, and their glycan variants among nonmucinous and mucinous cysts [17]. Using a highthroughput antibody microarray of 53 cyst fluid samples with histology, differences in protein expression and glycosylation variants were identified. Specifically, the wheat germ agglutinin detection of MUC5AC was significantly upregulated among mucinous cysts. In combination with CA 19-9, these two biomarkers provided a sensitivity of $87 \%$ and specificity of $86 \%$ for detection of potentially cancerous mucinous cysts.

Differentiating nonmucinous from mucinous cysts is useful but biomarkers that identify malignant mucinous cysts are needed. One small study suggests that Plectin-1 (Plec-1), a marker associated with pancreatic cancer, may be a candidate [18]. Using cyst fluid from seven patients with an established diagnosis of IPMN, Plec-1 was detected in all four malignant cysts and none of the three benign cysts.

These studies highlight the potential for cyst fluid biomarkers to improve the diagnosis of pancreatic cystic lesions. While encouraging, the current studies are limited in their design: the relatively small sample sizes and the selection bias in using surgical samples (i.e., cysts from patients selected for surgery may differ from those not selected for surgery), may overstate the true diagnostic accuracy of a candidate biomarker. Further testing and validation is needed to demonstrate that these candidate biomarkers significantly improve upon CEA, and should be incorporated into clinical practice.

Despite these limitations, there are reasons for optimism. First, these studies demonstrate that there are numerous potential biomarkers (both DNA and protein material) in the cyst fluid that are differentially expressed among cyst types. Their varying expression levels may in the near future accurately differentiate between not just nonmucinous and mucinous cysts, but also premalignant and malignant cysts. Second, these 
Table I. Diagnostic performance of highlighted cyst fluid biomarker studies for the detection of mucinous and malignant pancreatic cysts

\begin{tabular}{|c|c|c|c|c|c|c|c|}
\hline \multirow[b]{2}{*}{ Study } & \multirow[b]{2}{*}{$\begin{array}{l}\text { Cyst fluid } \\
\text { biomarker }\end{array}$} & \multirow[b]{2}{*}{ No. of patients } & \multirow[b]{2}{*}{$\begin{array}{l}\text { Criteria for } \\
\text { positive result }\end{array}$} & \multicolumn{2}{|c|}{ Detection of mucinous cysts } & \multicolumn{2}{|c|}{$\begin{array}{l}\text { Detection of cancer among } \\
\text { mucinous cysts }\end{array}$} \\
\hline & & & & Sensitivity & Specificity & Sensitivity & Specificity \\
\hline $\begin{array}{l}\text { Brugge } \\
\text { et al. [10] }\end{array}$ & CEA & 112 & $>192 \mathrm{ng} / \mathrm{ml}$ & $73 \%$ & $84 \%$ & NS & NS \\
\hline \multirow{5}{*}{$\begin{array}{l}\text { Khalid } \\
\text { et al. [II] }\end{array}$} & DNA & 113 & $+\mathrm{K}$-ras & $45 \%$ & $96 \%$ & NS & NS \\
\hline & & 76 & $+\mathrm{K}$-ras plus CEA & $82 \%$ & $67 \%$ & NS & NS \\
\hline & & 113 & MALA >65\% & $66 \%$ & $66 \%$ & NS & NS \\
\hline & & 113 & MALA >82\% & NS & NS & $82 \%$ & $82 \%$ \\
\hline & & 113 & $\begin{array}{l}\text { DNA amount } \\
(O D>10)\end{array}$ & NS & NS & $77 \%$ & $77 \%$ \\
\hline $\begin{array}{l}\text { Allen } \\
\text { et al. [16] }\end{array}$ & $\begin{array}{l}\text { Protein } \\
\text { expression }\end{array}$ & 59 & Not included & \multicolumn{4}{|c|}{$\begin{array}{l}34 \text { proteins were differentially expressed between SCN and IPMN }(P<0.05) \\
\text { provided diagnostic accuracy of } 92 \%\end{array}$} \\
\hline $\begin{array}{l}\text { Haab } \\
\text { et al. [17] }\end{array}$ & WGA - MUC5AC & 53 & $\begin{array}{l}+ \text { MUC5AC plus } \\
\text { CA } 19-9\end{array}$ & $87 \%$ & $86 \%$ & NS & NS \\
\hline $\begin{array}{l}\text { Bausch } \\
\text { et al. [18] }\end{array}$ & Plectin I & 7 & + Plectin I & NS & NS & $100 \%$ & $100 \%$ \\
\hline
\end{tabular}

CA 19-9, carbohydrate antigen 19-9; CEA, carcinoembryonic antigen; IPMN, intraductal papillary mucinous neoplasm; MALA, mean allelic loss amplitude; MUC5AC, mucin 5AC; NS, not significant or not studied; OD, optical density; SCN, serous cystic neoplasm; WGA, wheat germ agglutinin.

studies show that the volume of required cyst fluid for analysis is minute (6400 microliters) and easily obtainable by endoscopic ultrasound even from cysts less than $1 \mathrm{~cm}$ in diameter.

While we wait for these developments, what can cyst fluid analysis tell the clinician about a pancreatic cyst today? It is currently poor at diagnosing cancer, but is fairly accurate at picking out the mucinous cysts with malignant potential. When combined with other features such as an intracystic nodule, associated symptoms (including pancreatitis, pancreatic-type pain, or jaundice), and a large cyst size (generally considered greater than $3 \mathrm{~cm}$ ), it can help identify which premalignant cysts are at a relatively higher risk of malignant transformation. Patients with these features, if surgically fit, should be strongly considered for surgery. In the absence of these features, mucinous cysts can be monitored with a small risk of cancer progression.

Hopefully we will not have to wait too long for cyst fluid biomarkers that can predict the malignant transformation of premalignant cysts to reach the clinic.

\section{Abbreviations}

CA, carbohydrate antigen; CEA, carcinoembryonic antigen; IPMN, intraductal papillary mucinous neoplasm; MCN, mucinous cystic neoplasm; MUC, mucin; Plec-1, plectin 1; SCA, serous cystadenoma.

\section{Competing interests}

The author declares that he has no competing interests.

\section{Acknowledgements}

The author would like to thank Anson Lowe, MD, for his critical review of this manuscript.

\section{References}

I. Fernández-del Castillo C, Targarona J, Thayer SP, Rattner DW, Brugge WR, Warshaw AL: Incidental pancreatic cysts: clinicopathologic characteristics and comparison with symptomatic patients. Arch Surg 2003, I38:427-34.

2. Tanaka M, Chari S, Adsay V, Fernández-del Castillo C, Falconi M, Shimizu M, Yamaguchi K, Yamao K, Matsuno S: International consensus guidelines for management of intraductal papillary mucinous neoplasms and mucinous cystic neoplasms of the pancreas. Pancreatology 2006, 6:17-32.

FI000 Factor 8

Evaluated by Christos Dervenis 09 May 2006

3. Salvia R, Crippa S, Falconi M, Bassi C, Guarise A, Scarpa A, Pederzoli P: Branch-duct intraductal papillary mucinous neoplasms of the pancreas: to operate or not to operate? Gut 2007, 56:1086-90.

FI000 Factor 6

Evaluated by Atul Kumar 22 Oct 2007

4. Tang RS, Weinberg B, Dawson DW, Reber H, Hines OJ, Tomlinson JS, Chaudhari V, Raman S, Farrell Jj: Evaluation of the guidelines for management of pancreatic branch-duct intraductal papillary mucinous neoplasm. Clin Gastroenterol Hepatol 2008, 6:8I 5-9.

5. Pelaez-Luna M, Chari ST, Smyrk TC, Takahashi N, Clain JE, Levy MJ, Pearson RK, Petersen BT, Topazian MD, Vege SS, Kendrick M, Farnell MB: Do consensus indications for resection in branch duct intraductal papillary mucinous neoplasm predict malignancy? A study of 147 patients. Am J Gastroenterol 2007, 102: 1759-64

6. Walsh RM, Vogt DP, Henderson JM, Hirose K, Mason T, Bencsath K, Hammel J, Brown N: Management of suspected pancreatic cystic neoplasms based on cyst size. Surgery 2008, 144:677-85.

7. Allen PJ, D'Angelica M, Gonen M, Jaques DP, Coit DG, Jarnagin WR, DeMatteo R, Fong Y, Blumgart LH, Brennan MF: A selective approach 
to the resection of cystic lesions of the pancreas: results from 539 consecutive patients. Ann Surg 2006, 244:572-82.

8. Correa-Gallego C, Ferrone CR, Thayer SP, Wargo JA, Warshaw AL, Fernández-Del Castillo $C$ : Incidental pancreatic cysts: do we really know what we are watching? Pancreatology 2010, I0:144-50.

9. Le Borgne J, de Calan L, Partensky C: Cystadenomas and cystadenocarcinomas of the pancreas: a multiinstitutional retrospective study of $\mathbf{3 9 8}$ cases. French Surgical Association. Ann Surg 1999, 230:152-61.

10. Brugge WR, Lewandrowski K, Lee-Lewandrowski E, Centeno BA, Szydlo T, Regan S, del Castillo CF, Warshaw AL: Diagnosis of pancreatic cystic neoplasms: a report of the cooperative pancreatic cyst study. Gastroenterology 2004, I 26:1330-6.

II. Khalid A, Zahid M, Finkelstein SD, LeBlanc JK, Kaushik N, Ahmad N, Brugge WR, Edmundowicz SA, Hawes RH, McGrath KM: Pancreatic cyst fluid DNA analysis in evaluating pancreatic cysts: a report of the PANDA study. Gastrointest Endosc 2009, 69:1095-102.

12. van der Waaij LA, van Dullemen HM, Porte RJ: Cyst fluid analysis in the differential diagnosis of pancreatic cystic lesions: a pooled analysis. Gastrointest Endosc 2005, 62:383-9.

13. Jacobson BC, Baron TH, Adler DG, Davila RE, Egan J, Hirota WK, Leighton JA, Qureshi W, Rajan E, Zuckerman MJ, Fanelli R, WheelerHarbaugh J, Faigel DO; American Society for Gastrointestinal
Endoscopy: ASGE guideline: The role of endoscopy in the diagnosis and the management of cystic lesions and inflammatory fluid collections of the pancreas. Gastrointest Endosc 2005, $61: 363-70$.

14. Das A, Wells CD, Nguyen CC: Incidental cystic neoplasms of pancreas: what is the optimal interval of imaging surveillance? Am J Gastroenterol 2008, I03:1657-62.

15. Sawhney MS, Devarajan S, O'Farrel P, Cury MS, Kundu R, Vollmer CM, Brown A, Chuttani R, Pleskow DK: Comparison of carcinoembryonic antigen and molecular analysis in pancreatic cyst fluid. Gastrointest Endosc 2009, 69: I 106-10.

16. Allen PJ, Qin LX, Tang L, Klimstra D, Brennan MF, Lokshin A: Pancreatic cyst fluid protein expression profiling for discriminating between serous cystadenoma and intraductal papillary mucinous neoplasm. Ann Surg 2009, 250:754-60.

17. Haab BB, Porter A, Yue T, Li L, Scheiman J, Anderson MA, Barnes D, Schmidt CM, Feng Z, Simeone DM: Glycosylation variants of mucins and CEACAMs as candidate biomarkers for the diagnosis of pancreatic cystic neoplasms. Ann Surg 2010, 25 I:937-45.

18. Bausch D, Mino-Kenudson M, Fernandez-Del Castillo C, Warshaw AL, Kelly KA, Thayer SP: Plectin-I is a biomarker of malignant pancreatic intraductal papillary mucinous neoplasms. J Gastrointest Surg 2009, I3:1948-54. 